Discussion Paper No. 13-016

Sovereign Risk Premia:

The Link Between Fiscal Rules and Stability Culture

Friedrich Heinemann, Steffen Osterloh, and Alexander Kalb

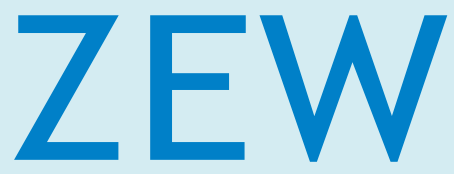

Zentrum für Europäische Wirtschaftsforschung $\mathrm{GmbH}$

Centre for European

Economic Research 
Discussion Paper No. 13-016

\title{
Sovereign Risk Premia: The Link Between Fiscal Rules and Stability Culture
}

\author{
Friedrich Heinemann, Steffen Osterloh, \\ and Alexander Kalb
}

Download this ZEW Discussion Paper from our ftp server:

http://ftp.zew.de/pub/zew-docs/dp/dp13016.pdf

Die Discussion Papers dienen einer möglichst schnellen Verbreitung von neueren Forschungsarbeiten des ZEW. Die Beiträge liegen in alleiniger Verantwortung der Autoren und stellen nicht notwendigerweise die Meinung des ZEW dar.

Discussion Papers are intended to make results of ZEW research promptly available to other economists in order to encourage discussion and suggestions for revisions. The authors are solely responsible for the contents which do not necessarily represent the opinion of the ZEW. 


\section{Non-technical summary}

The credibility crisis regarding the sustainability of public debt has transformed the markets for government bonds in the Euro area. A new sensitivity of creditors for the risk of sovereign default has pushed up financing costs of several euro member countries or has even cut them off from market access. Currently, policy makers try to enhance their fiscal reputation through the establishment of better European and national fiscal rules, particular in form of the debt brakes prescribed by the European Fiscal Compact. The hope is that, independent from the current budgetary performance, new fiscal rules send out credible signals to the markets and cut short the way towards lowering the risk spread.

In our paper we study the determinants of sovereign risk premia in the EU countries between 1992 and 2008. Our contribution addresses two interrelated questions: First, do fiscal rules impact on sovereign risk premia in Europe? And second, is any such observable link really causal or rather the consequence of different national "stability cultures", which arise from differing historical institutions or fiscal preferences?

In our empirical analysis, we try to shed light on this issue by employing several types of stability preference related proxies. These proxies are related to a country's past stability performance, government characteristics and survey results related to general trust. We find evidence that these indicators have an influence on risk premia. Moreover, they dampen the measurable impact of fiscal rules on risk premia. The estimated positive effect of fiscal rules on market confidence in the early years of EMU can thus mainly be explained by the fact that mainly high-stability countries introduced such constraints. Our results indicate that these stability-oriented countries would not have had a significantly lower financial market reputation if they had not established fiscal rules. Thus, for these countries strict fiscal rules may be rather interpreted as a confirmation of the underlying fiscal preferences of the voters and their political representatives. Still, even if this is true, it does not preclude the possibility that the new establishment of strict rules - such as intended by the Fiscal Compact - is relevant for fiscal reputation in countries with a lack of historical stability orientation. Our results rather point to the fact that fiscal rules have the largest potential for countries with particularly poor stability culture in the past: for these countries, the effect of rules on risk premia is significantly stronger than for highstability countries. It seems that these countries could benefit from the establishment of debt brakes which is intended by the Fiscal Compact. 


\section{Das Wichtigste in Kürze}

Die Vertrauenskrise hinsichtlich der Tragbarkeit der öffentlichen Verschuldung hat die Märkte für Staatsanleihen des Euroraums nachhaltig verändert. Eine neue Sensitivität der Investoren für das Risiko von staatlichen Zahlungsausfällen hat die Finanzierungskosten zahlreicher Euro-Mitgliedstaaten in die Höhe getrieben oder sogar deren Marktzugang abgeschnitten. Eine von der Politik derzeit verfolgte Strategie besteht in dem Bestreben, das Vertrauen in die Fiskalpolitik mittels der Einrichtung von verbesserten europäischen oder nationalen Fiskalregeln, insbesondere in der Form der vom Fiskalpakt vorgeschriebenen Schuldenbremsen, zu erhöhen. Damit wird auch die Hoffnung verbunden, dass diese Fiskalregeln, unabhängig von der derzeitigen Haushaltslage, glaubwürdige Signale an die Märkte aussenden und so mit dazu beitragen können, kurzfristig die Risikoaufschläge zu verringern.

In diesem Papier untersuchen wir die Determinanten der Risikoprämien der Staatsanleihen der EU-Mitgliedstaaten zwischen 1992 und 2008. Unser Beitrag wendet sich zwei miteinander verbundenen Fragestellungen zu: Erstens, beeinflussen Fiskalregeln die Höhe von Risikoprämien auf europäische Staatsanleihen? Und zweitens, ist ein derartiger beobachtbarer Zusammenhang tatsächlich kausal oder aber die Konsequenz von sich zwischen den Staaten unterscheidenden "Stabilitätskulturen", die das Ergebnis unterschiedlicher historischer Entwicklungen oder fiskalischer Präferenzen sind?

In unserer empirischen Analyse versuchen wir diese Fragen durch die Verwendung verschiedener Arten von Proxyvariablen für die Stabilitätspräferenzen zu klären. Diese Proxyvariablen beziehen sich auf die historische Stabilitätsperformanz eines Staates, Regierungscharakteristika sowie Umfrageergebnisse zum generellen interpersonellen Vertrauen. Es zeigt sich, dass diese Indikatoren die Höhe der Risikoprämien beeinflussen. Zudem dämpfen sie den messbaren Einfluss von Fiskalregeln auf Risikoprämien. Der beobachtbare positive Effekt von Fiskalregeln auf das Vertrauen der Märkte in den ersten Jahren der Währungsunion lässt sich somit vor allem dadurch erklären, dass überwiegend ohnehin stabilitätsorientierte Länder solche Beschränkungen eingeführt haben. Unsere Ergebnisse deuten darauf hin, dass diese stabilitätsorientierten Länder nicht über ein bedeutend geringeres Vertrauen der Finanzmärkte verfügt hätten, falls sie keine Fiskalregeln eingeführt hätten. Somit lassen sich die strengen Fiskalregeln in diesen Ländern eher als ein weiterer Ausdruck der ohnehin vorhandenen fiskalischen Präferenzen der Wähler und ihrer politischen Vertreter ansehen. Jedoch schließt dieses nicht die Möglichkeit 
aus, dass die Neueinführung von strengen Regeln, wie sie etwa durch den Fiskalpakt beabsichtigt wird, bedeutsam für das Marktvertrauen gegenüber Ländern mit einer historisch geringen Stabilitätsorientierung ist. Unsere Ergebnisse deuten sogar darauf hin, dass Fiskalregeln das größte Potenzial für Länder mit einer in der Vergangenheit besonders schwach ausgeprägten Stabilitätskultur aufweisen: Für diese Länder ist der von Fiskalregeln ausgehende Effekt auf die Höhe der Risikoaufschläge signifikant stärker als für eher stabilitätsorientierte Staaten. Es scheint, dass solche Staaten von der im Fiskalpakt vorgesehenen Einführung von Schuldenbremsen in besonderem Maße profitieren könnten. 


\title{
Sovereign risk premia: The link between fiscal rules
}

\section{and stability culture}

\author{
Friedrich Heinemann \\ (ZEW Mannheim and University of Heidelberg) \\ Steffen Osterloh $* a$ \\ (German Council of Economic Experts) \\ Alexander Kalb ${ }^{a}$ \\ (BayernLB, Department of Country Risk \& Sector Analysis)
}

This version: March 2013

\begin{abstract}
There is a growing empirical literature studying whether fiscal rules reduce borrowing costs. Nevertheless, it remains an open question whether these rules are effective genuinely or just because they mirror fiscal preferences of politicians and voters. In our analysis of European bond spreads, we shed light on this issue by employing several types of stability preference related proxies. These proxies refer to a country's past stability performance, government characteristics and survey results related to general trust. We find evidence that these preference indicators have an influence on risk premia and dampen the measurable impact of fiscal rules. Yet, the interaction of stability preferences and rules points to a particular potential of fiscal rules in countries with a historically low stability culture.
\end{abstract}

Classification: H63, E62, G12

Keywords: fiscal preferences, fiscal rules, debt crisis, bond markets

*Corresponding author:

Sachverständigenrat zur Begutachtung der gesamtwirtschaftlichen Entwicklung; Gustav-StresemannRing 11; 65189 Wiesbaden; Germany; +49-611-752668; steffen.osterloh@destatis.de

${ }^{a}$ The opinions expressed in this paper reflect the personal views of the authors and do not necessarily reflect those of the BayernLB or the German Council of Economic Experts. 


\section{Introduction}

The credibility crisis regarding the sustainability of public debt has transformed the markets for government bonds in the Euro area. A new sensitivity of creditors for the risk of sovereign default has pushed up financing costs of several euro member countries or has even cut them off from market access. This fundamental change in risk awareness has multiplied the interest rate costs associated with a deteriorating fiscal position.

Politics have reacted in various ways ranging from drastic consolidation efforts over European emergency credit lines to the search for a framework for orderly defaults. Apart from these approaches, one strategy is to foster fiscal reputation through better European and national fiscal rules. In this context, important actors like the Commission's president José Manuel Barroso or the German chancellor Angela Merkel have called for a "new stability culture" in Europe, ${ }^{1}$ which is supposed to reassure the bond markets about the new reliability of consolidation strategies and a brighter fiscal future.

A crucial question in this context is, of course, to which extent 'stability culture' can swiftly be changed by politicians or legislators. The answer depends on the precise definition since this term has at least two connotations. First, it can be related to the rules which constrain a country's fiscal policy. Second, it may point to long run fiscal preferences of citizens and/or politicians as well as national institutional characteristics, which are a heritage of a country's history. Both dimensions are fundamentally distinct. Whereas preferences can hardly be changed through short-run political measures, fiscal rules are open for such adjustments.

Currently, policy makers try to foster fiscal reputation through the establishment of better European and national fiscal rules. In particular, the Fiscal Compact which was agreed by the European Heads of State of Government in December 2011 prescribes that all participating countries (all EU member states without the United Kingdom and the Czech Republic) will have to introduce national fiscal rules by the end of 2013 (European Central Bank, 2012). These rules have to be introduced in the national legislation, preferably in the form of constitutional provisions, and they have to fulfill certain requirements, in particular they have to limit the structural deficit of the general government at $0.5 \%$ of

\footnotetext{
${ }^{1}$ Barroso: "Our priority is putting order into our public finances. We need fiscal consolidation and a new financial stability culture in Europe." (Introductory remarks at a joint press point with the German Chancellor Angela Merkel, June 11, 2011); Merkel proposed a "new stability culture" in Europe to overcome the turmoil that has battered the euro on the foreign exchange markets (AFP, May 19, 2010).
} 
GDP. The hope is that, independent from the current budgetary performance, such fiscal rules send out credible signals and cut short the way towards lowering the risk spread. Indeed, there is some empirical evidence in the context of US states, EU countries or Swiss cantons that properly designed fiscal rules can actually reduce risk spreads (see survey below). The available empirical evidence, however, is limited to the rules-dimension of stability culture so that all conclusions are necessarily preliminary.

The essential problem is that these rules may reflect stability oriented preferences of a country's voters and politicians and, thus, the effect of fiscal rules on risk premia can be a result of a common-cause-interdependence: Conservative fiscal preferences might have led both to the establishment of rules and to lower risk premia. This criticism is well known from the literature on the effectiveness of fiscal rules (Poterba, 1996): A correlation of strict fiscal rules and low public deficits cannot necessarily be interpreted causally. Voters who dislike public debt will also favour strict debt limits. If this is the case, the observed fiscal link between rules and fiscal policy outcomes could be spurious. This methodological problem is of immediate policy relevance. A new rule as such does not change preferences, in particular if it is established as a consequence of external pressure. If the markets rather pay attention to preferences than to written rules, they could remain sceptical vis-à-vis a high debt country. Rules which seem to work in one country might then fail in another. Hence, we have to address different empirical questions: First, is the establishment of fiscal rules largely driven by stability-oriented preferences? Second, does the impact of fiscal rules on risk premia survive if fiscal preferences are taken into account through appropriate proxies? And third, could fiscal rules have a different impact in countries with high and low stability preferences?

Thus, it is the key objective of our contribution to integrate the stability culture dimension into the study of risk premium determinants in Europe and to address the questions above. Specifically, we want to understand how both dimensions of stability culture - rules and preferences - influence government bond risk premia and how they interact.

The paper is structured as follows: In a first step, we give a brief overview of the relevant literature including the few studies explicitly devoted to the issue of stability culture and fiscal performance. In the empirical section, we first check the robustness of the (one-dimensional) link between rules and risk premia in Europe. Afterwards, we 
include different proxies for a country's stability culture to shed light on the impact of these proxies and their interaction with the effect of fiscal rules on risk premia.

\section{The relevant literature}

\section{$2.1 \quad$ Effects of fiscal rules}

The studies on the effectiveness of fiscal rules are one important point of reference. Fiscal rules are shown to be an effective obstacle to a build-up of public debt. This strengthens the expectation that they also might influence the expectations of investors and, consequently, the level of risk premia. The literature on fiscal rules' effectiveness has been inspired by the establishment of tax and expenditure limits in US federal states since the end of the 1970s and the Maastricht fiscal rules in Europe in the 1990s. The effectiveness of two different types of rules has been studied: first, rules for the budgetary processes (Hallerberg and von Hagen, 1999; von Hagen and Harden, 1995), and second, numerical fiscal rules. The impact of numerical fiscal rules has been looked at in several regional contexts: for the US (e.g. Eichengreen and Bayoumi, 1994; Poterba, 1996), for Europe (e.g. Debrun, 2000; Debrun et al., 2008), for OECD countries (e.g. Dahan and Strawczynski, 2010) and for Swiss cantons and municipalities (e.g. Feld and Kirchgässner, 2008; Krogstrup and Wälti, 2008). Overall, this literature is moderately optimistic that strict rules can be effective; however, some of the studies point to circumventing activities through creative accounting (von Hagen and Wolff, 2006).

If such a link between rules and fiscal policy outcomes is anticipated by financial markets, the reaction of a rational investor is unambiguous: He should assess the sustainability of a country's fiscal stance more positive if it has a fiscal rule in place and demand a lower compensation for the default risk of the sovereign bond than for a comparable country without any fiscal rules in place. This should contribute to a lower level of risk premia for countries with stricter fiscal rules. ${ }^{2}$

Yet, empirical studies dealing with such a direct impact of fiscal rules on risk premia are less frequent. ${ }^{3}$ For the US, Eichengreen and Bayoumi (1994) find a significant impact

\footnotetext{
${ }^{2}$ A theoretical discussion of the link between fiscal rules and risk premia in a model of sovereign default and its implications for optimal target values for fiscal rules can be found in Hatchondo et al. (2012).

${ }^{3}$ Note that this literature does not consider a possible (long-term) indirect effect of fiscal rules: rules
} 
of strong rules on US states' borrowing conditions. Poterba and Rueben (1999) arrive at a more differentiated view: Whereas strong deficit and expenditure lower yields, tax limits make a state more risky from the investors' perspective and increase yields. Poterba and Rueben (2001) focus on the interaction between deficits and rules. A sudden deficit increase lifts a state's financing costs, but the size of the rise is limited if the state has a strict rule. This result points to a credibility effect even in times of fiscal stress. Lowry and Alt (2001) modify the result and show that repeated deficits erode the credibility effect of strict rules at bond markets. All these works, however, suffer from the fact that they do not consider actual financial market data but are based on data from the 'Chubb Relative Value Survey'. This survey is conducted by an insurance company which asked 25 traders to evaluate 'hypothetical' general obligations of US states. Johnson and Kriz (2005) emphasise the disadvantages of this data, which seems to bias the estimated effects upwards: By using financial market data, they only find a very modest effect of fiscal rules on bond spreads (between 2.4 and 3.3 basis points).

For Europe, Hallerberg and Wolff (2008) make use of an index measuring the institutional strength of the finance minister and, thus, build on the insights on budgetary procedures. They find that deficits generally drive risk premia, but this link is weaker with strong institutions. Iara and Wolff (2011) focus on numerical fiscal rules and study their impact on risk premia for the initial eleven Euro area countries for the years 1999 to 2009 in a panel estimation. The authors make use of the European Commission's Fiscal Rule Index (FRI) (European Commission, 2006). Using a standard fixed effects estimation approach (which is comparable to most of the literature, including our baseline model), they do not find an overall significant effect of fiscal rules on risk spreads, but they do find a significant impact if they interact the FRI with the general risk aversion of the market. Thus, fiscal rules only have a negative effect on bond spreads in a market environment where risk sensitivity is high. Finally, Feld et al. (2012) find a robust negative effect of fiscal rules on bond spreads for Swiss cantons; this effect is quantitatively relatively strong (more than 10 basis points for strong rules). Compared to US state rules or national rules, this strong effect seems reasonable given the relatively stringent design of fiscal rules in Switzerland. They are, for instance, often associated with strong enforcement mechanisms in the form of automatic tax adjustments after non-compliance with the numerical targets of the rules.

can also improve the country's budgetary position, which is then reflected in lower bond spreads. 


\subsection{Stability culture and fiscal preferences}

So far, none of the existing studies on the link between fiscal rules and risk premia explicitly integrate fiscal preference proxies. In this regard, the paper most closely related to ours is the work by Bernoth and Wolff (2008), who find that signals of creative accounting increase bond spreads in European countries. Even though the paper is not explicit about this, one might easily argue that fiscal transparency is a dimension strongly related to a country's stability culture.

Generally, there are only few approaches which explicitly take account of fiscal preferences for the empirical explanation of fiscal outcomes and they focus either on politicians' or citizens' preferences. With respect to political preferences, a common approach in the literature is to equate fiscal conservatism with general political conservatism. With this approach, a government's party affiliation is used as an indicator of fiscal preferences (Holtz-Eakin, 1988; Poterba, 1995). Bohn and Inman (1996) make use of a CBS/New York Times opinion poll with respect to a self-assessment as 'conservative' (for the period 1976-1988). It is an obvious shortcoming of any such approach that political ideology simply defined as left-wing or right-wing - is not necessarily representative for the economic policy preferences of parties and, hence, not equal to fiscal conservatism in the sense of an aversion against public debt. A more explicit approach is only applied by Pujol (2009), who tries to distil an indicator of fiscal attitude concerning deficits and debt for the US presidents from a quantitative analysis of key documents with respect to the frequency of certain words and arguments. The evidence demonstrates that preferences cannot simply be reduced to a simple deterministic product of economic conditions and a President's party affiliation.

Stix (2011) directly measures the fiscal preferences of citizens using a self-conducted Austrian survey which includes focussed questions on public debt preferences. He shows that individual preferences are clearly related to self-interest but also to perceptions of distributional fairness among the current generation and the credibility of the government's fiscal plans. Heinemann and Hennighausen (2012) exploit survey results from Germany. The relevant survey question focuses on the trade-off between reducing public borrowing and increasing taxes or reducing benefits. Their results imply that one main driver of individual preferences for higher public debt are self-interest motives predicted by Ricardian reasoning. Moreover, interpersonal trust contributes positively to the willingness to 
consolidate, whereas party preferences do not exercise a strong influence. Survey questions like the ones developed by Stix or Heinemann and Hennighausen would be ideal for our analysis if they were available on a cross-country basis. Unfortunately, they are not.

Dafflon and Pujol (2001) exploit the preferences revealed by Swiss voters in fiscal referenda. A voting behaviour is classified as conservative if it supports tax increases, expenditure cuts or deficit and expenditure limits. Their indicator of fiscal preferences helps to explain Swiss cantonal deficits in the context of a standard explanatory model. Pujol and Weber (2003) build on the cantonal indicator from Dafflon and Pujol (2001) and check to which extent these fiscal preferences can be treated as exogenous in empirical exercises. For that purpose, they estimate a model for explaining fiscal preferences. It turns out that party preferences and religious denomination are important, but language has the heaviest impact on these preferences. In particular, the German speaking share of the cantonal population is strongly related to favouring fiscal conservatism. Equally, Funk and Gathmann (2011) employ an indicator for time-varying fiscal preferences based on voting behaviour in federal ballots. The inclusion of this fiscal preference indicator does not significantly affect the result according to which (Swiss) direct democracy reduces spending. Hence, the evidence implies that citizens' fiscal preferences are - at least in the short-run - exogenous, although the measurement is challenging. This gives strong support to the expectation that the fiscal preferences of citizens have to be regarded as rather stable over time and that they are deeply rooted in the culture and history of a country, meaning its stability culture. The Funk and Gathmann measure is applied by Krogstrup and Wälti (2008) who show that the impact of fiscal rules on cantonal deficits is still detectable even if there is a control for fiscal preferences.

Concerning the interplay of stability culture and institutions, some findings from the monetary policy literature are relevant to our approach. In particular, Hayo (1998) looks for the link of anti-inflation culture, central bank independence and inflation performance. In this view, economic culture is defined as the values and attitudes of a population with regard to all aspects related to the economic system; consequently, it is strongly influenced by historical experience. The outcome of this historical process is a country-specific consensus on price stability, which is reflected in inflation rates. The paper finds that the central bank independence in a country is strongly related to such public attitudes towards inflation, which is a result of a historical feedback process. The findings challenge the or- 
thodox economic view that central bank independence as such creates monetary stability. The problem is that both explanations - either institutions or preferences shape inflation performance - are characterised by observational equivalence. In a similar vein, Scheve (2004) detects a substantial cross-country heterogeneity in inflation aversion revealed in surveys, which also points to differences in stability cultures between countries.

Overall, the literature points to the importance of a country's stability culture for fiscal or monetary outcomes. This stability culture has both a time-variant and a long-term dimension, which also has important implications for the financial market assessment of sovereign bond issuers. Imagine a government comes into power which is regarded as fiscally irresponsible or too weak to undertake necessary reforms: A rational investor should then lose the trust in the countries' future budgetary situation and, hence, demand a higher compensation for the increased default risk of sovereign debt. The same holds true for countries which are generally considered to have a lack of 'stability culture'. Investors should always demand a higher compensation from them, even if the budgetary position at that point of time does not differ significantly from other countries. These considerations set the path for our empirical investigations in the following section.

\section{The baseline}

In a first step, we provide a baseline estimation without an explicit modeling of fiscal preferences. For that purpose, we augment the existing analyses of the sovereign debt market in the Euro area before the start of the financial crisis. Of particular relevance for our work is the most recent paper by Iara and Wolff (2011) who study the effect of fiscal rules in panel of Euro area countries. We complement their approach by adding a number of non-Euro members ${ }^{4}$ and by extending the sample period by the years prior to the start of the monetary union, in some cases back to 1993. As dependent variable, we use the 10year spot rate yield differential to Germany. To account for exchange rate risk, we follow Favero et al. (1997) and correct the spreads by subtracting the spread of fixed interest rate swaps denominated in the different currencies. Our estimation model is motivated by the broad literature on the determinants of risk premia of bonds in the EMU; notably,

\footnotetext{
${ }^{4}$ Our database includes Belgium, Denmark, Germany, Finland, France, Greece, Ireland, Italy, the Netherlands, Austria, Portugal, Sweden, Slovak Republic, Spain, the Czech Republic and the United Kingdom.
} 
the following influences are discussed in the literature (see, e.g., Manganelli and Wolswijk, 2009): (i) budgetary position, (ii) general risk aversion, (iii) liquidity.

We restrict our analysis to the 'quiet times' at the European bond markets before the evolving debt crisis was reflected in exploding spreads and therefore do not extend the sample beyond 2008. The reason for this is that the recent literature identifies a major structural break in the determinants of yield spreads around that time. Since then, the quantitative impact of the countries' fiscal situation on risk premia intensified (e.g., von Hagen et al., 2011), some countries' spreads disconnected from the underlying fundamentals due to self-fulfilling market sentiments (De Grauwe and Ji, forthcoming), contagion effects between countries emerged (Mink and de Haan, forthcoming) and systemic risk stemming from the risk of a break up of the Euro zone was priced in bond yields (Di Cesare et al., 2012). Empirical analyses which apply time-varying coefficient models (Aßmann and Boysen-Hogrefe, 2012; Bernoth and Erdogan, 2012) suggest that the autumn of 2008 can be considered as a break date, which falls together with the Lehman collapse and the announcement of baking rescue packages in the euro area in October (Ejsing and Lemke, 2011); as a consequence, the maximum spread in the euro area reached for the first time a value of more than 100 basis points. Consequently, we adopt October 2008 as the end point of our sample.

Our baseline specification is as follows:

$$
\begin{aligned}
& \text { BondSpread }_{i, t}=\beta_{1} \text { Debt }_{i, t}+\beta_{2}{\text { De } \text { ficit }_{i, t}+\beta_{3} \text { Liquidity }_{i, t}+\beta_{4} \text { RiskAversion }_{t}}^{+\beta_{5} \text { EMU }_{i, t}+\beta_{6} \text { FRI }_{i, t}+\beta_{7} \text { Interaction }_{i, t}+\gamma_{i}+\lambda_{t}+\epsilon_{i, t}}
\end{aligned}
$$

The bond spread as well as the debt and deficit (both in percentage of GDP) are measured relative to Germany (the descriptive statistics can be found in table 3 in the appendix). Following Hallerberg and Wolff (2008), we measure a country's bond market liquidity as the share of the country's debt in total EU debt. Fiscal data are annual and originate from the Ameco database. Our measure of general risk aversion is the yield difference between US corporate bonds (rating Baa) and US treasuries (again as usual in the literature: Bernoth et al., 2004; Codogno et al., 2003). Financial market data are monthly and originate from Datastream. Moreover, we include an EMU dummy in order to account for possible effects of the monetary union. We add year dummies $\left(\lambda_{t}\right)$ in order to capture time-specific influences. Finally, $\gamma_{i}$ represents country fixed effects and $\epsilon_{i, t}$ the error term. 
The strength of fiscal rules is measured by the European Commission's (2006) Fiscal Rule Index $(F R I)$. This index combines quantitative and qualitative characteristics of a country's existing fiscal rules and measures their strength by the following criteria: legal framework, nature of the bodies in charge of monitoring and enforcement, enforcement mechanisms and media visibility.

We add several modifications to the baseline model which further shed light on the effects of fiscal rules on risk premia. First, in addition to the direct impact of fiscal rules on the level of bond spreads, we also study their interaction with the debt level and the public deficit. This can help to answer the question whether the existence of fiscal rules can at least partially - counteract the loss of confidence which results from a deterioration of national budgetary figures. Second, in a further disclosure, we split the FRI in the types of rule (i.e. budget balance rules, debt rules, expenditure rules and revenue rules). This breakdown is possible based on the detailed information of each rule, including an assessment of its strength, which is provided by the European Commission's 'Database on numerical fiscal rules' (European Commission, 2006).

Moreover, in addition to fixed effects estimations - which are applied in Iara and Wolff (2011) and are for good reasons standard in the literature - we complement our analysis with the Fixed Effects Vector Decomposition (FEVD) estimator. This method was developed by Plümper and Troeger (2007) in order to estimate time-invariant and rarely changing variables in panel data models with unit effects. ${ }^{5}$ In contrast to fixed effects estimations, it does not only make use of the time variation of a given variable within a country, but also considers the variation of the variable between the countries. Technically, the estimation of the FEVD estimator takes the following three steps: (i) A fixed effects model is estimated; (ii) the unit effects are regressed on the time-invariant variables; (iii) the first stage is re-estimated including the error term of the second stage.

Since for many countries the fiscal rule index does not fluctuate much or sometimes not at all (Greece, e.g., has no fiscal rule at any point of time, so that these observations are practically dropped in the FE estimations), this estimation method seems to be very

\footnotetext{
${ }^{5}$ Note that the FEVD estimator was criticised on theoretical grounds by Breusch et al. (2011) and Greene (2011), which led to an extensive discussion which is documented in a symposium published in Political Analysis 19(2). From this it can be concluded that Plümper and Troeger (2007) seem to have overplayed the advantages of the FEVD compared to competing estimators such as random effects and Hausman-Taylor, whereby it is demonstrated that FEVD is a special case of the Hausman-Taylor IV approach. Nevertheless, Plümper and Troeger (2011) demonstrate that FEVD has favourable finite sample properties over the competing approaches.
} 
suitable for the data at hand (Krogstrup and Wälti, 2008), use the same approach for their analysis the budgetary impact of fiscal rules in Swiss cantons). It dramatically increases the efficiency of the estimates. Yet, a potential correlation between an unobserved fixed effect and the rarely changing fiscal rule variable would mean that estimates with the FEVD estimator are biased, even though Plümper and Troeger, 2007; Plümper and Troeger, 2011 demonstrate that the fixed effect vector decomposition estimator is the least biased estimator when time-variant and time-invariant variables are correlated with the unit effects (compared to competing methods, such as random effects or Hausman-Taylor estimators). We are fully aware of this trade-off between bias and inefficiency and will back to it in the discussion of our results.

Table 1 presents the results for our baseline estimates, using both the fixed effects (a) and the FEVD (b) estimator. Models (1a) and (1b) are the starting point and do not yet include the FRI; (2a) and (2b) include the FRI; the further specifications (3a-5a, 3b-5b) also include interactions of the FRI with the deficit, the debt and the risk aversion, respectively.

With respect to the standard control variables, the following findings emerge: The impact of debt (relative to Germany) has the expected consistent positive only in the FEVD estimations; yet, it remains insignificant. ${ }^{6}$ The deficit (relative to Germany) is significant in several cases and always pushes up yield spreads. While liquidity (at least for our rough indicator) remains insignificant throughout all specifications, the risk aversion indicator proves to be of large importance: Across all specifications, it is highly significant and sizeable. An increase of the US corporate-sovereign yield spread by 100 basis points pushes up sovereign risk premia in Europe by 7 to 9 basis points. Ceteris paribus, EMU countries tend to have significantly higher risk premia with the FEVD estimator. This is in line with the view that the euro accession implies the loss of national control over the domestic currency, closes the inflationary exit from high public debt and, hence, increases the risk of default. ${ }^{7}$

Including our key variable of interest, the FRI, leads to differing results depending on the choice of the estimator. The strength of fiscal rules is only marginally different

\footnotetext{
${ }^{6}$ We use the 4.0 beta version of the FEVD; in this version, a defect in previous versions of the Stata code is corrected which calculated standard errors which were too small as discussed by Greene (2011).

${ }^{7}$ Note that any exchange rate risks which are associated with inflation risks are disregarded through the correction of interest rate spreads by the swap spreads.
} 


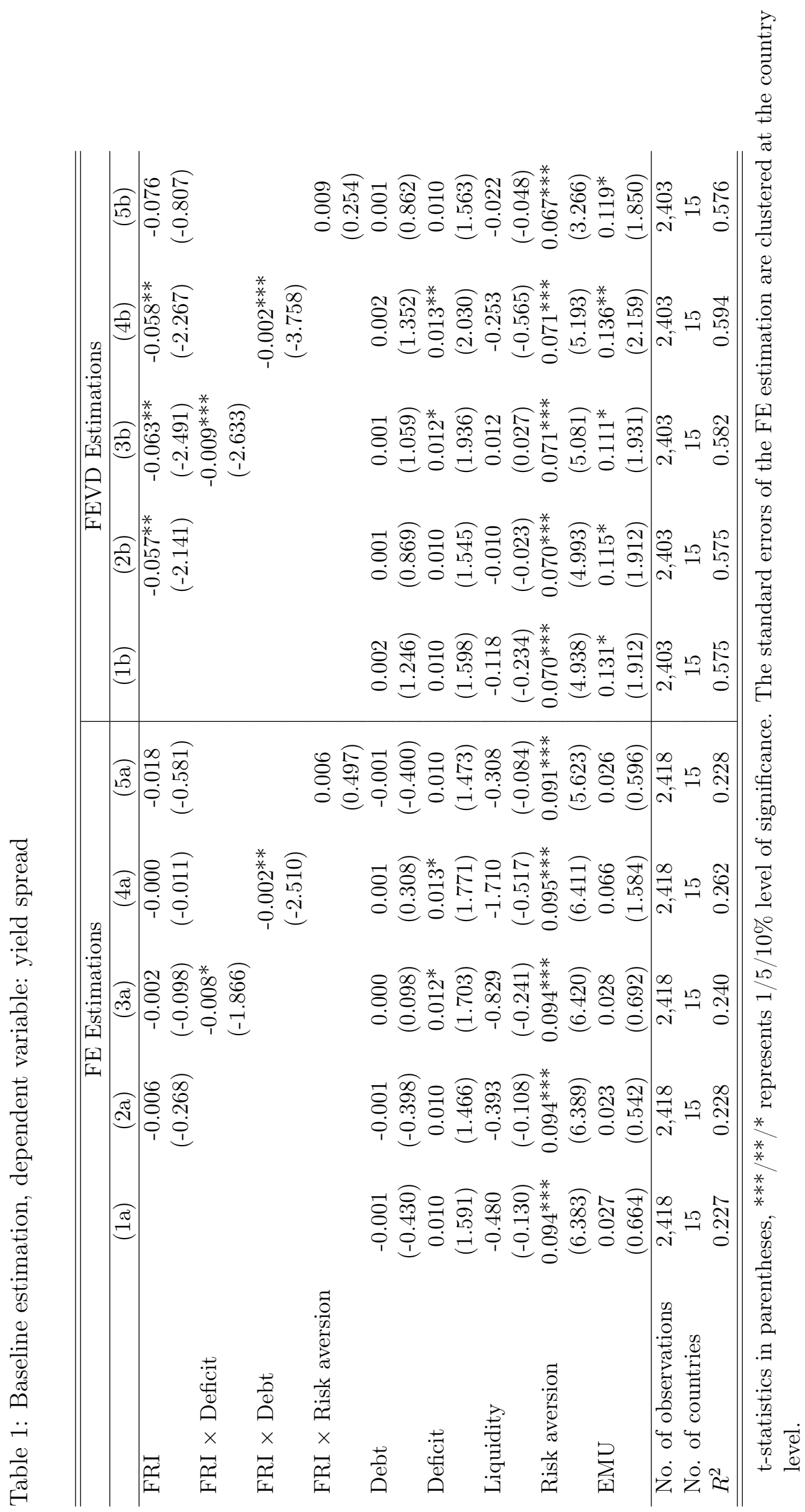


from zero in the fixed effects estimation (2a). With the FEVD approach, however, it is quite sizeable, negative and reaches a five percent level of significance. This finding suggests that an increase of the fiscal rule index from its lowest level (Greece) to its highest level (UK) reduces the bond spread by 17.9 basis points. The insignificance of the FRI in the FE estimation does not come as a surprise given that the FRI does not have a large time variation. Consequently, this hampers the identification with fixed country effects. In other words, this finding implies that countries which introduced a fiscal rule were on average not rewarded by the financial markets in the form of lower risk premia. The significant coefficient of FRI in the FEVD estimation (2b), however, tells a different story. This effect is obviously largely due to the variation of the index between countries. Such a between-effect is completely absorbed when fixed effects are included in the FE estimation. The FEVD results suggest that countries with fiscal rules in place pay lower risk premia than countries without such rules.

Before turning to the impact of our stability proxies (and in how far they can help to explain this discrepancy), we have to look at the further specifications of the baseline model. Including the interactions between the FRI and the fiscal variable points to the importance of stringent fiscal rules: For countries with high deficits or debt levels, stringent fiscal rules are able to limit yield increases, but they may be of lower relevance for countries with relatively good fiscal data. This finding is quantitatively very similar for both estimation approaches. This implies a type of conditional importance of fiscal rules for countries with a deterioration of their budgetary position. The FRI-risk aversion does not show a significant effect.

Table 4 in the appendix reports the FEVD results for the FRI sub-indicators, which refer to the type of rule. Mainly the budgetary balance rules and the debt rules seem to contribute to the overall significant effect in the FEVD estimations. In particular, the budgetary balance rule has a dampening effect on risk premia, which is statistically significant when tested individually. 


\section{Consideration of stability culture proxies}

\subsection{Proxies of stability culture}

A superficial reading of the above FEVD results would predict a strong direct effect of fiscal rules on risk premia. This conclusion, however, is premature as long as differences in stability preferences are ignored in the analysis. As argued at the outset, these differences can be a strong source of heterogeneity between countries, which could lead to a bias in the estimations. Especially the apparent discrepancy between the FE and FEVD results calls for a careful discussion of this issue. Obviously, the FE estimations suffer from a serious lack of variation in the FRI variable leading to inefficient estimations, whereas it is quite obvious that the FEVD might be biased due to an omitted variable bias. The variable which might simultaneously affect both the existence of rules and expectations of financial markets is the fiscal preference of citizens and politicians. Therefore, it is desirable to augment the benchmark model by the inclusion of proxies for stability-oriented fiscal preferences.

Any such attempt is, however, confronted with a scarcity of direct fiscal preference

indicators. An ideal indicator would measure voters' (and governments') aversion against public debt in a consistent way across countries and over time. The problem is that this specific preference relation has never been included in one of the leading cross-country surveys. There are conceptually convincing ways to derive such indicators, e.g. from referendum data. Yet, this approach is only available in very specific circumstances, such as for the Swiss cantons (see above section 2.2), and is no option to derive comparative European data. In the following, we then experiment with three different types of proxies: (i) the historically revealed stability culture, (ii) political preferences of the government as well as government stability and (iii) social capital in a country.

\subsubsection{Revealed stability preferences: past inflation rates}

The first type of proxy is based on the idea of revealed preferences. Past macroeconomic performance indicators may allow some conclusions with regard to a country's preferences and institutions related to economic stability. Of course, these indicators must not directly be based on fiscal performance because fiscal rules may co-determine fiscal outcomes so 
that both factors are too closely linked for any identification purpose. One alternative is to base revealed stability preference on past inflation performance. This is legitimate if both fiscal and monetary stability are the outcome of one common underlying preference for stability. Under this assumption, we can measure a country's debt aversion through past inflation rates. The advantage over fiscal performance indicators is that past monetary performance is not influenced directly by fiscal rules we have to include in our empirical testing. This approach is also motivated by the literature mentioned above, which mainly focused on inflation as an indicator of economic stability. As the introduction of the euro did away with any monetary sovereignty of eurozone member countries, historical inflation rates from a time not yet influenced by expectations regarding a common currency should be used. Hence, we employ average inflation rates of the period from 1980 to 1990.

A first plausibility check whether historical inflation rates behave as general stability preference proxies is to look for a link between them and the existence of fiscal rules. In Figure 1, we plot the average level of the fiscal rule index between 2000 and 2008 against the historical inflation rates (between 1980 and 1990) of the European countries. A clear negative relation can be seen. This indicates that this proxy behaves as expected in theory: A low average inflation rate signals ambitious stability preferences and is correlated with the existence of strong fiscal rules.

Figure 1: Correlation of average historical inflation rates (1980-90) and fiscal rule index

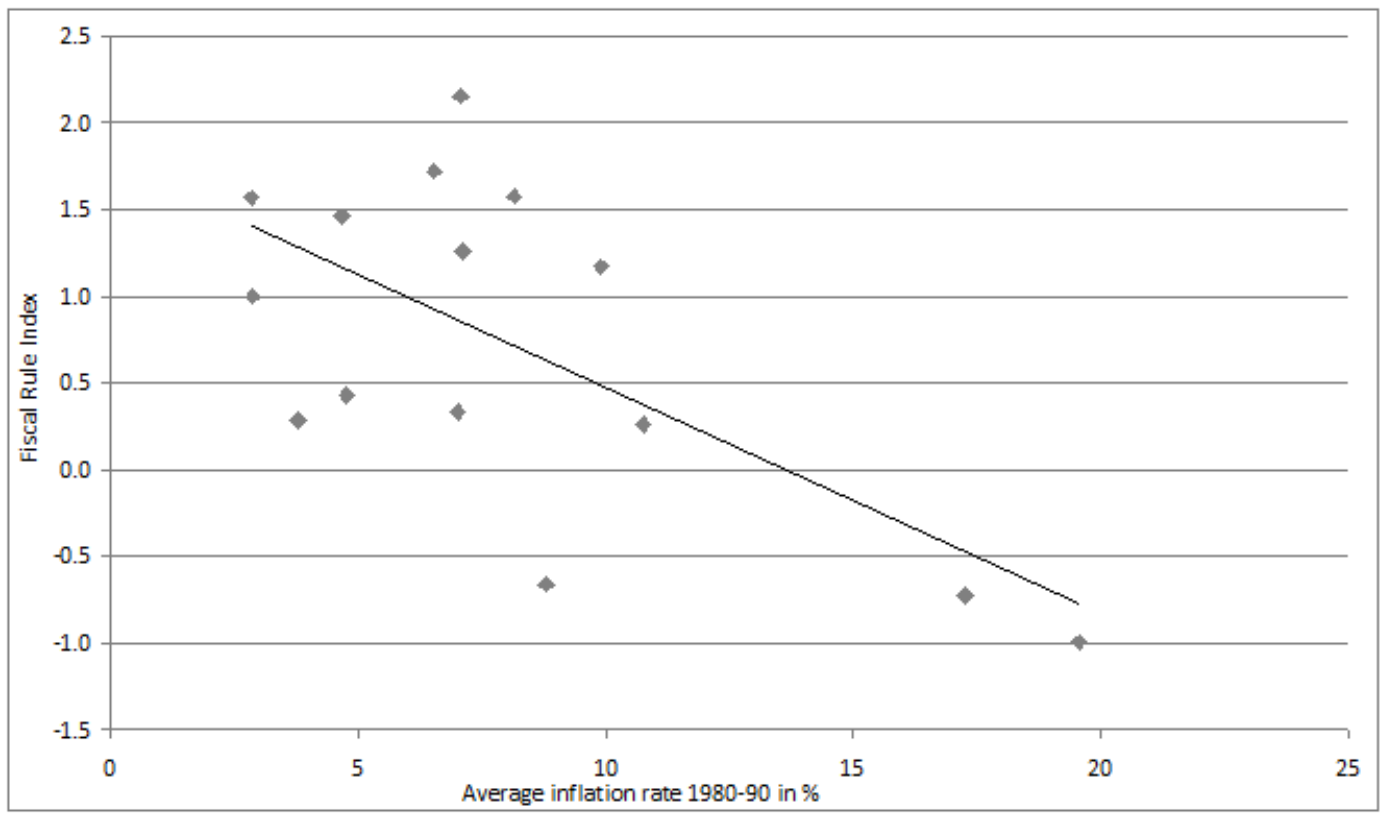




\subsubsection{Government related ideological and stability indicators}

The second strategy to arrive at meaningful stability proxies is to follow the literature cited above (section 2.2), which derives fiscal preference from information on government characteristics, such as the predominant ideology. Any such approach, however, should take account of the criticism that the left to right-wing differentiation as such is not more than a very crude measure when it comes to single policy areas, which is widely acknowledged in the political science literature. Thus, this differentiation is not very informative for a party's fiscal stability preference.

Therefore, we go beyond the crude left-right distinction and use more detailed data on the preferences of parties concerning the size of the public sector, which are based on the data provided by Benoit and Laver (2006). This data set is derived from a large scale expert survey and covers all major parties in Europe. One sub-indicator also classifies parties according to their fiscal preferences. This measure is defined as the trade-off between lower taxes and higher public spending. Parties are assessed based on the question to which extent they either opt for a low tax/low public spending or a high tax/high public spending approach. Note that our expectations concerning the direction of this variable's impact on risk premia are ambiguous as discussed by Imbeau (2004). Since one group aims at increasing spending whereas the other aims at cutting taxes, both purposes might contribute to a loss of market confidence in sound public finances.

Based on these partisan fiscal preferences, we can calculate the government's center of gravity (seat-weighted positions of the parties represented in the government), which accounts for the fiscal conservatism of each (coalition) government at a certain point of time. As an additional advantage, this measure also provides us with useful cross-sectional variation in the political preferences between countries, which would not be possible with the use of simple left-right dummies. The Benoit-Laver data explicitly accounts for preference differences of parties from the same party family between countries. Consider for instance the British Conservatives, which are in this measure located more 'pro low taxes' (16.4) than their German counterpart, the CDU (14.4), whereas the German Liberals (FDP) even reach a value of 18.7 .

A further relevant government characteristic is its stability. Governments with a high likelihood of failure and low assertiveness might suffer from distrust by the markets. This 
expectation is derived from the literature on 'weak governments' (Roubini and Sachs, 1989). According to this literature, governments without a clear majority find it harder to balance the budget after an external shock, which contributes to a deterioration of the budgetary position. To account for this effect, we add a dummy variable which indicates caretaker and minority governments according to the classification of Woldendorp et al. (2000).

\subsubsection{Population trust and 'social capital'}

A third approach is to infer voters' fiscal preferences from survey results which are available on a comparative cross-country basis. Since a direct indicator of citizens' fiscal preferences is unavailable, we have to search for indicators for which a link to fiscal preferences is plausible. Recent micro evidence by Heinemann and Hennighausen (2012) implies that interpersonal trust is a natural candidate. Their results are based on a representative survey in Germany and show that trusting citizens show a greater support for consolidation efforts.

Interpersonal trust is a prominent survey variable which is in the focus of the literature on 'social capital' (Putnam, 1995). In this literature, trust in the reliability and honesty of other people is regarded as crucial for overcoming all kinds of social coordination failures. A general idea is that a high degree of trust simplifies economic transactions, pro-social behavior and the provision of public goods. For example, it has been shown that trust has a strong positive impact on the functioning of institutions and it is a major determinant of the quality of government (Knack, 2002). Furthermore, it is already shown that trusting citizens are more ready to accept structural reforms (Heinemann and Tanz, 2008), less likely to move activities into the informal sector (D'Hernoncourt and Méon, 2012) or to evade taxes (Feld and Frey, 2002), and that trust fosters investment and growth (Zak and Knack, 2001). The general explanation is that voters in a society of mutual trust are more likely to accept compromises and strategies with longer-term horizons since they trust in the good motives of their fellow citizens and their governments. Unsustainable public debt can clearly be classified as a phenomenon of a societal coordination failure. In conflicted and polarised societies, a high level of public debt must be expected (Alesina and Drazen, 1991; Roubini and Sachs, 1989). These considerations point to the usefulness of trust as a stability preference proxy: Countries with a high degree of mutual trust should rather 
be able to overcome coordination problems also with respect to public debt. This should translate into a more trustworthy national fiscal policy from the investors' perspective.

For our quantification of the trust variable, we follow the social capital literature and use survey data from the World Value Survey and the European Value Survey. The trust variable refers to the share of citizens who responded positively to the following question: "Generally speaking, would you say that most people can be trusted or that you need to be very careful when dealing with people?". The values between the available waves were interpolated.

\subsection{Empirical results}

In table 2, we complement our FEVD estimates with our three proxies for stability preferences. First, we test their effect on the EU countries' risk premia without the consideration of the fiscal rule index. Specifications (1) to (3) include each proxy separately and (4) combines them all in one regression. Overall, the results are in line with our expectations formulated above.

Both political indicators show a statistically significant effect. A weak government increases the risk premia by 6 basis points. For the fiscal conservatism indicator, we were not able to formulate a clear a priori sign prediction. The empirical results point to a lower credibility of 'low tax - low spending' fiscal strategies. A government which is devoted to lowering taxes and spending reduces financial market confidence to a larger extent compared to a government devoted to high spending and higher taxes. Apparently, the former has an even lower credibility of respecting the government budget constraint. Interestingly, this is in line with the recent finding by Belke and Potrafke (2012) that the monetary policy of an independent central bank tends to be more conservative (and thus more stability-oriented) under left-wing governments.

Past monetary stability has the expected positive effect, which is also statistically significant. Higher historical inflation rates in the pre-EMU era (measured as the natural logarithm of the average yearly inflation rate between 1980 and 1990) lead to higher risk premia today. This effect can be quantified as follows: A doubling of the average inflation rate in the 1980s increases the bond spread by 6.8 basis points. $^{8}$

\footnotetext{
${ }^{8}$ Note again that this effect cannot be due to a country-individual depreciation expectation. We observe bond spreads either for Eurozone countries or employ spreads adjusted for exchange rate expectations in
} 


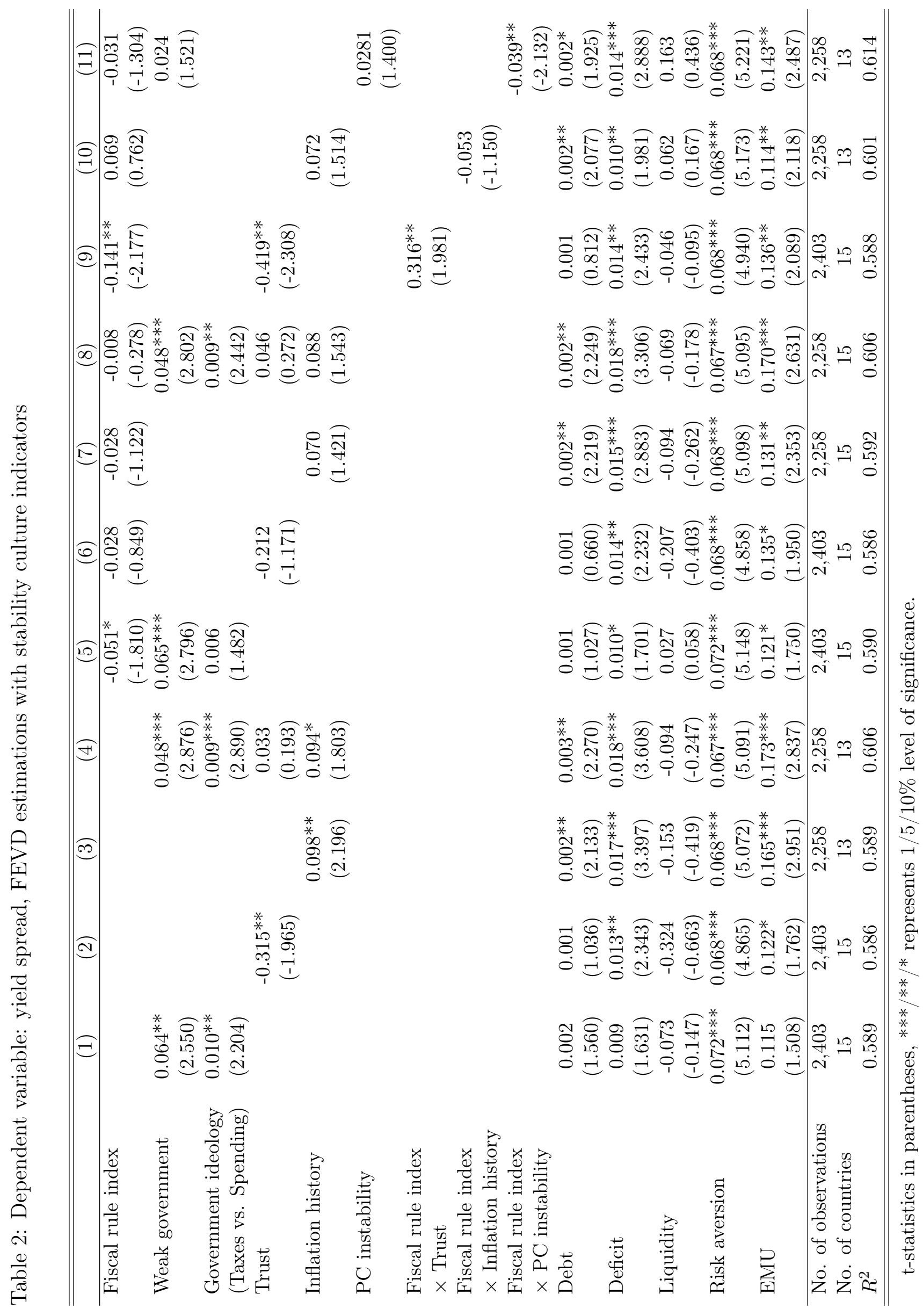


Finally, high trust seems to have the expected positive reputation effect: A high share of trusting citizens lowers risk premia. The combined inclusion of all stability preference proxies confirms the high significance of our government related indicators and of past inflation stability, whereas trust loses significance.

Next, we add the fiscal rule index to the estimates. We have to compare the estimated coefficients for the fiscal rule index with the specification $(2 \mathrm{~b})$ in table 1, i.e. the FEVD estimates of the model without the consideration of indicators for the stability culture. Recall that the estimated coefficient was -0.057 and significant at the $5 \%$ level.

As can be seen in specification (5), the consideration of the political variables deflates the effect of the fiscal rules variable; however, it stays significant at the $10 \%$ level. The inclusion of trust (6) or the inflation history (7) leads to a halving of the estimated coefficient of the fiscal rule index and a loss of the significance levels, respectively. Finally, the inclusion of all proxies for stability culture (specification (8)) leads to a drop of the estimated coefficient for the fiscal rules level to -0.008. This result is quantitatively very similar to the estimated coefficient in the fixed effects model (which is -0.006 , see specification (2a) in table 1). These results suggest that the finding of lower risk premia in countries with stronger fiscal rules can almost entirely be explained by the fact that mainly countries with a more pronounced stability culture adopted stronger fiscal rules.

Finally, we are interested in whether the estimated effect of the fiscal rule index on risk premia is conditional on the countries' different historical stability culture. For this purpose, we interact the fiscal rule index with our two largely time-invariant proxies of stability culture: trust and historical inflation rates. As can be seen in specification (9), the interaction with trust has a positive sign and is statistically significant at the $5 \%$ level. This indicates that the effect of fiscal rules is stronger in countries which show a lower trust level. This finding is confirmed in specification (10), where we apply the historical inflation rates as stability proxy. Here, the interaction term's coefficient is negative, which again indicates that the link between fiscal rules and financial market confidence is stronger in countries which have a low-stability history.

In order to demonstrate that these effects are important in quantitative terms, we use a principal components analysis and extract the first component of our (largely) timethe case of non-Euro countries. Hence, we are confident that stability preference revealed in past inflation rates drive the result. 
invariant measures (see Tabellini, 2010, for a similar approach). The interaction of the generated variable, 'PC instability', with the fiscal rules index again reflects that the impacts of rules is bigger in countries with a low value of the stability proxies (11). We then plot the estimated marginal effects of the fiscal rules on credit spreads conditional on the 'PC instability' values (see figure 2). As can be seen, in countries with low values of 'PC instability', i.e. countries with a more pronounced stability culture, the effect of the fiscal rule variable is very close to zero (e.g., for Austria the corresponding value on the $\mathrm{x}$-axis is on average -0.72 , the lowest value can be found for the Netherlands, -1.96). Yet, for countries with a rather high 'PC instability' value, the estimated marginal effects are highly negative, i.e. fiscal rules reduce the risk spreads. For those countries, the effects stay below zero the $10 \%$ significance level as indicated by the confidence band. In particular, for countries such as Spain ('PC instability': 0.80), Italy (0.82) or Greece (2.05), the estimated marginal effects are highly negative at p-values below 0.1 .

Figure 2: Marginal effects of fiscal rule index on bond spreads (based on specification (11), table 2)

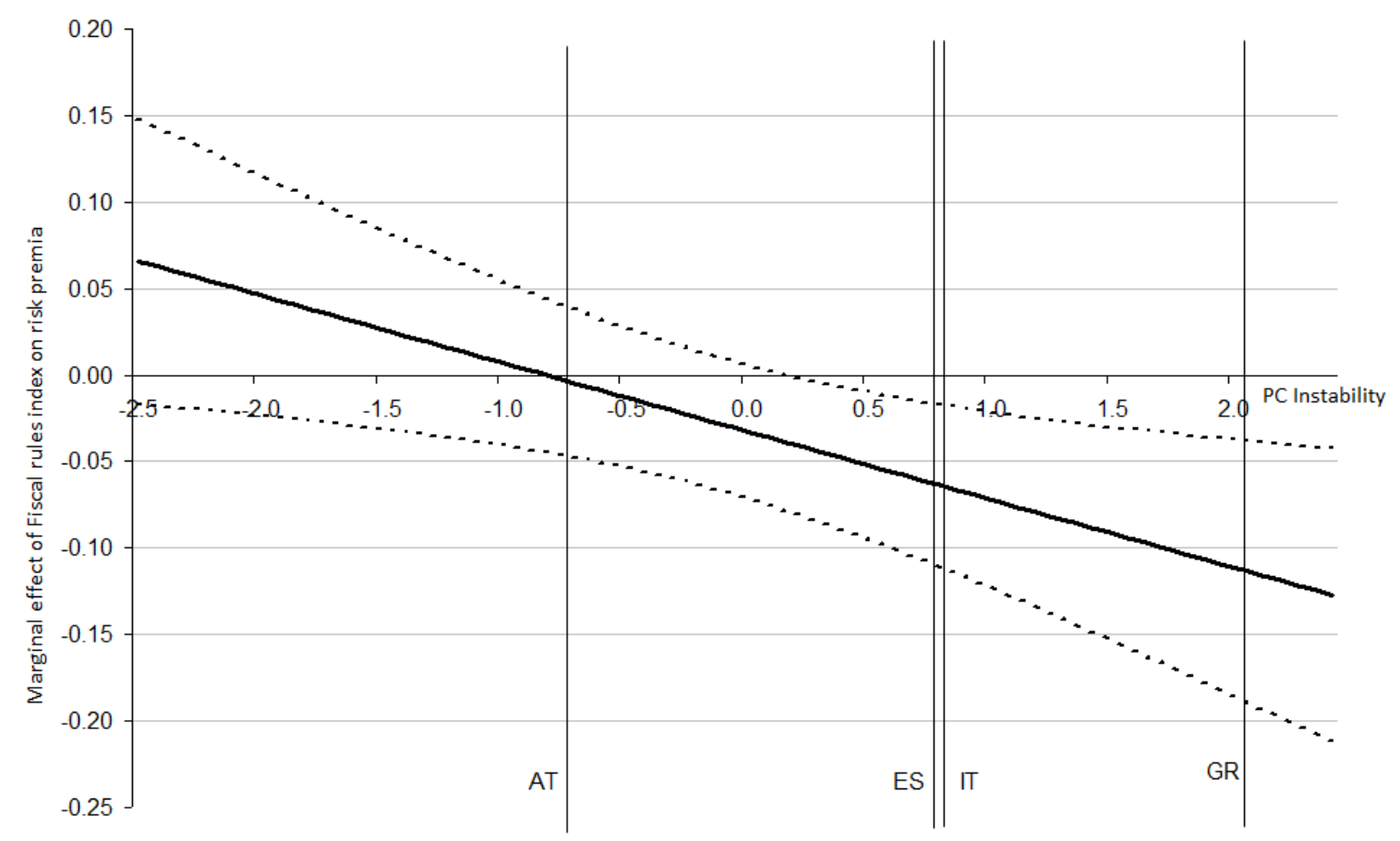

Dashed lines indicate the upper and lower bound of the $90 \%$ confidence interval. AT: Austria, ES: Spain, IT: Italy, GR: Greece.

These findings point to an asymmetry in the impact of fiscal rules between high and low-stability countries. It appears that countries with a rather low revealed stability preference or a low trust level are particularly rewarded for strict fiscal rules. This asymmetry does not come as a surprise since for high stability countries strict fiscal rules do not imply 
a true change from the perspective of financial markets, whereas these rules could change the picture for low stability countries.

\section{Conclusion}

Have fiscal rules really had a genuine impact on risk premia in the past, even if they have been highly correlated with a country's general stability orientation? And could new fiscal rules in high debt countries contribute to a build-up of fiscal reputation? Our results indicate that there may be a negative answer to the former and a positive answer to the latter question. There appears to be a correlation between strict rules and stability preferences in the past. Countries with lower risk premia have benefitted both from an anti-debt consensus in the population and from stricter fiscal rules. Furthermore, our results indicate that these stability-oriented countries would not have had a significantly lower financial market reputation if they had not established fiscal rules. Thus, for these countries strict fiscal rules may be rather interpreted as another indicator which reflects the underlying fiscal preferences of the voters and their political representatives.

Still, even if this is true, it does not preclude the possibility that the new establishment of strict rules is relevant for fiscal reputation in countries with a lack of historical stability orientation. Our results rather reflect the fact that these countries found it difficult to establish these rules by themselves in 'normal times'. However, in the course of the crisis several member states introduced new fiscal rules and after 2013 all member states of the Euro area will be obliged to have national rules which comply with the guidelines established in the Fiscal Compact. One could argue that the introduction of these rules was the result of external pressure: either due to the pressure of the financial markets (Spain, Italy) or of the European partners, since the ratification of the Fiscal Compact was a prerequisite to be eligible for future bail-out funding through the newly established European Stability Mechanism (ESM). An essential result of our interaction analysis is that fiscal rules nevertheless have the largest potential to restore financial market confidence for countries with particularly poor revealed stability preferences in the past. There is already some evidence from federal states that even if rules are introduced through 'external pressure', one can still expect positive effects from their introduction. These recent empirical findings demonstrate that sub-national fiscal rules can indeed be effective in in- 
creasing fiscal soundness even when they are not introduced 'voluntarily' by a lower level but imposed by the central government (Grembi et al., 2012, for Italian municipalities; Foremny, 2011, for European regions). Our results may be regarded as further evidence along these lines and, hence, cast a cautiously optimistic light at the Fiscal Compact and its possible contribution to building a better fiscal reputation of European member countries.

\section{References}

Alesina, A., Drazen, A., 1991. Why are stabilizations delayed? American Economic Review 81 (5), 1170-1188.

Aßmann, C., Boysen-Hogrefe, J., 2012. Determinants of government bond spreads in the euro area: in good times as in bad. Empirica 39 (3), 341-356.

Belke, A., Potrafke, N., 2012. Does government ideology matter in monetary policy? A panel data analysis for OECD countries. Journal of International Money and Finance 31 (5), 1126-1139.

Benoit, K., Laver, M., 2006. Party Policy in Modern Democracies. Cambridge University Press, Cambridge.

Bernoth, K., Erdogan, B., 2012. Sovereign bond yield spreads: A time-varying coefficient approach. Journal of International Money and Finance 31 (3), 639-656.

Bernoth, K., von Hagen, J., Schuknecht, L., 2004. Sovereign risk premia in the European government bond market, ECB Working Paper No. 369, Frankfurt (Main).

Bernoth, K., Wolff, G. B., 2008. Fool the markets? Creative accounting, fiscal transparency and sovereign risk premia. Scottish Journal of Political Economy 55 (4), 465487.

Bohn, H., Inman, R. P., 1996. Balanced-budget rules and public deficits: evidence from the U.S. states. Carnegie-Rochester Conference Series on Public Policy 45 (1), 13-76.

Breusch, T., Ward, M. B., Nguyen, H. T. M., Kompas, T., 2011. On the fixed-effects vector decomposition. Political Analysis 19 (2), 123-134. 
Codogno, L., Favero, C., Missale, A., 2003. Yield spreads on EMU government bonds. Economic Policy 18 (37), 503-532.

Dafflon, B., Pujol, F., 2001. Fiscal preferences and fiscal performance: Swiss cantonal evidence. International Public Management Review 2 (2), 54-78.

Dahan, M., Strawczynski, M., 2010. Fiscal rules and composition bias in OECD countries. CESifo Working Paper Series 3088, Munich.

De Grauwe, P., Ji, Y., forthcoming. Self-fulfilling crises in the eurozone: An empirical test. Journal of International Money and Finance.

Debrun, X., 2000. Fiscal rules in a monetary union: A short-run analysis. Open Economies Review 11 (4), 323-358.

Debrun, X., Moulin, L., Turrini, A., Ayuso-i-Casals, J., Kumar, M. S., 2008. Tied to the mast? National fiscal rules in the European Union. Economic Policy 23 (54), 297-362.

D’Hernoncourt, J., Méon, P.-G., 2012. The not so dark side of trust: Does trust increase the size of the shadow economy? Journal of Economic Behavior \& Organization 81 (1), $97-121$.

Di Cesare, A., Grande, G., Manna, M., Taboga, M., 2012. Recent estimates of sovereign risk premia for euro-area countries. Questioni di Economia e Finanza (Occasional Papers) 128, Bank of Italy, Rome.

Eichengreen, B., Bayoumi, T., 1994. The political economy of fiscal restrictions: Implications for Europe from the United States. European Economic Review 38 (3-4), 783-791.

Ejsing, J., Lemke, W., 2011. The Janus-headed salvation: Sovereign and bank credit risk premia during 2008-2009. Economics Letters 110 (1), 28-31.

European Central Bank, 2012. A fiscal compact for a stronger Economic and Monetary Union. ECB Monthly Bulletin May, 79-94.

European Commission, 2006. Public Finances in EMU 2006. European Economy No. 3/2006. European Commission, Brussels.

Favero, C. A., Giavazzi, F., Spaventa, L., 1997. High yields: The spread on German interest rates. Economic Journal 107 (443), 956-985. 
Feld, L. P., Frey, B. S., 2002. Trust breeds trust: How taxpayers are treated. Economics of Governance 3 (2), 87-99.

Feld, L. P., Kalb, A., Moessinger, M.-D., Osterloh, S., 2012. Sovereign bond market reactions to fiscal rules and no-bailout clauses: The Swiss experience, paper presented at the ECB Conference "Reforming EU Fiscal Governance", 13-14 December 2012, Frankfurt/Main.

Feld, L. P., Kirchgässner, G., 2008. On the effectiveness of debt brakes: The Swiss experience. In: Neck, R., Sturm, J.-E. (Eds.), Sustainability of Public Debt. MIT Press, Cambridge, pp. 223-255.

Foremny, D., 2011. Vertical aspects of sub-national deficits: The impact of fiscal rules and tax autonomy in European countries, University of Bonn.

Funk, P., Gathmann, C., 2011. Does direct democracy reduce the size of government? New evidence from historical data, 1890-2000. Economic Journal 121 (557), 1252-1280.

Greene, W., 2011. Fixed effects vector decomposition: A magical solution to the problem of time-invariant variables in fixed effects models? Political Analysis 19 (2), 135-146.

Grembi, V., Nannicini, T., Troiano, U., 2012. Policy responses to fiscal restraints: A difference-in-discontinuities design. IZA Discussion Papers 6952, Institute for the Study of Labor (IZA), Bonn.

Hallerberg, M., von Hagen, J., 1999. Electoral institutions, cabinet negotiations, and budget deficits in the european union. In: Poterba, J., von Hagen, J. (Eds.), Fiscal Institutions and Fiscal Performance. University of Chicago Press, Chicago, pp. 209232.

Hallerberg, M., Wolff, G., 2008. Fiscal institutions, fiscal policy and sovereign risk premia in EMU. Public Choice 136 (3), 379-396.

Hatchondo, J. C., Martinez, L., Roch, F., 2012. Fiscal rules and the sovereign default premium. Working Paper 12-01, Federal Reserve Bank of Richmond.

Hayo, B., 1998. Inflation culture, central bank independence and price stability. European Journal of Political Economy 14 (2), 241-263. 
Heinemann, F., Hennighausen, T., 2012. Understanding public debt preferences. Finanz Archiv: Public Finance Analysis 68 (4), 406-430.

Heinemann, F., Tanz, B., 2008. The impact of trust on reforms. Journal of Economic Policy Reform 11 (3), 173-185.

Holtz-Eakin, D., 1988. The line item veto and public sector budgets: Evidence from the states. Journal of Public Economics 36 (3), 269-292.

Iara, A., Wolff, G. B., 2011. Rules and risk in the euro area, Bruegel Working Paper 10/2011, Brussels.

Imbeau, L. M., 2004. Public deficits and surpluses in federated states: A review of the public choice empirical literature. Journal of Public Finance and Public Choice 23 (3), $123-145$.

Johnson, C. L., Kriz, K. A., 2005. Fiscal institutions, credit ratings, and borrowing costs. Public Budgeting \& Finance 25 (1), 84-103.

Knack, S., 2002. Social capital and the quality of government: Evidence from the U.S. states. American Journal of Political Science 46 (4), 772-785.

Krogstrup, S., Wälti, S., 2008. Do fiscal rules cause budgetary outcomes? Public Choice 136 (1), 123-138.

Lowry, R. C., Alt, J. E., 2001. A visible hand? Bond markets, political parties, balanced budget laws, and state government debt. Economics \& Politics 13 (1), 49-72.

Manganelli, S., Wolswijk, G., 2009. What drives spreads in the euro area government bond market? Economic Policy 24 (58), 191-240.

Mink, M., de Haan, J., forthcoming. Contagion during the greek sovereign debt crisis. Journal of International Money and Finance.

Plümper, T., Troeger, V. E., 2011. Fixed-effects vector decomposition: Properties, reliability, and instruments. Political Analysis 19 (2), 147-164.

Plümper, T., Troeger, V. E., 2007. Efficient estimation of time-invariant and rarely changing variables in finite sample panel analyses with unit fixed effects. Political Analysis $15(2), 124-139$. 
Poterba, J. M., 1995. Balanced budget rules and fiscal policy: Evidence from the states. National Tax Journal 48 (3), 329-336.

Poterba, J. M., 1996. Budget institutions and fiscal policy in the U.S. states. American Economic Review 86 (2), 395-400.

Poterba, J. M., Rueben, K., 1999. State fiscal institutions and the U.S. municipal bond market. In: Poterba, J., von Hagen, J. (Eds.), Fiscal Institutions and Fiscal Performance. University of Chicago Press, Chicago, pp. 181-208.

Poterba, J. M., Rueben, K. S., 2001. Fiscal news, state budget rules, and tax-exempt bond yields. Journal of Urban Economics 50 (3), 537-562.

Pujol, F., 2009. Measuring US presidents' political commitment for fiscal discipline between 1920 and 2008. In: Imbeau, L. M. (Ed.), Do They Walk Like They Talk? Vol. 15 of Studies in Public Choice. Springer, New York, pp. 83-107.

Pujol, F., Weber, L., 2003. Are preferences for fiscal discipline endogenous? Public Choice $114(3-4), 421-444$.

Putnam, R. D., 1995. Tuning in, tuning out: The strange disappearance of social capital in America. PS: Political Science and Politics 28 (4), 664-683.

Roubini, N., Sachs, J. D., 1989. Political and economic determinants of budget deficits in the industrial democracies. European Economic Review 33 (5), 903-933.

Scheve, K., 2004. Public inflation aversion and the political economy of macroeconomic policymaking. International Organization 58, 1-34.

Stix, H., 2011. Does the broad public want to consolidate public debt? - The role of fairness and of policy credibility. Working Papers 167, Oesterreichische Nationalbank (Austrian Central Bank), Vienna.

Tabellini, G., 2010. Culture and institutions: Economic development in the regions of Europe. Journal of the European Economic Association 8 (4), 677-716.

von Hagen, J., Harden, I. J., 1995. Budget processes and commitment to fiscal discipline. European Economic Review 39 (3-4), 771-779. 
von Hagen, J., Schuknecht, L., Wolswijk, G., 2011. Government bond risk premiums in the EU revisited: The impact of the financial crisis. European Journal of Political Economy $27(1), 36-43$.

von Hagen, J., Wolff, G. B., 2006. What do deficits tell us about debt? Empirical evidence on creative accounting with fiscal rules in the EU. Journal of Banking \& Finance 30 (12), $3259-3279$.

Woldendorp, J. J., Keman, H., Budge, I., 2000. Party Government in 48 Democracies (1945-1998): Composition - Duration - Personnel. Kluwer Academic Publishers, Dordrecht.

Zak, P. J., Knack, S., 2001. Trust and growth. Economic Journal 111 (470), 295-321.

\section{Appendix}

Table 3: Descriptive statistics

\begin{tabular}{|c|c|c|c|c|c|c|c|}
\hline Variable & Unit & Frequency & Mean & Std. Dev. & Min & Max & Source \\
\hline Bond spread & in percentage points & monthly & 0.14 & 0.248 & -0.62 & 2.03 & Datastream \\
\hline Debt & $\begin{array}{l}\text { in } \% \text { of GDP, in } \\
\text { relation to Germany }\end{array}$ & yearly & 2.19 & 28.169 & -42.70 & 88.41 & Ameco \\
\hline Deficit & $\begin{array}{l}\text { in } \% \text { of GDP, in } \\
\text { relation to Germany }\end{array}$ & yearly & -0.29 & 3.125 & -8.33 & 8.16 & Ameco \\
\hline Liquidity & in $\%$ of $\mathrm{EU}$ debt & yearly & 0.06 & 0.067 & 0.00 & 0.25 & Ameco \\
\hline Risk aversion & in percentage points & monthly & 2.24 & 0.755 & 1.29 & 6.04 & Datastream \\
\hline EMU & $\begin{array}{l}\text { Dummy variable }=1 \\
\text { if EMU member }\end{array}$ & yearly & 0.48 & 0.500 & 0 & 1 & Own calculations \\
\hline $\begin{array}{l}\text { FRI (Fiscal } \\
\text { rule index) }\end{array}$ & Index & yearly & 0.37 & 1.041 & -1 & 2.15 & $\begin{array}{l}\text { European Commission } \\
\text { Fiscal Rules Database }\end{array}$ \\
\hline $\begin{array}{l}\text { Index balanced } \\
\text { budget rules }\end{array}$ & Index & yearly & 1.98 & 2.742 & 0 & 7.85 & $\begin{array}{l}\text { Own calculations } \\
\text { based on Fiscal } \\
\text { Rules Database }\end{array}$ \\
\hline Index debt rules & Index & yearly & 0.74 & 1.986 & 0 & 8.35 & Ibid. \\
\hline $\begin{array}{l}\text { Index expenditure } \\
\text { rules }\end{array}$ & Index & yearly & 1.05 & 1.845 & 0 & 6.53 & Ibid. \\
\hline Index revenue rules & Index & yearly & 0.73 & 1.963 & 0 & 6.53 & Ibid. \\
\hline Weak government & $\begin{array}{l}\text { Dummy variable }=1 \\
\text { if minority or } \\
\text { caretaker government }\end{array}$ & monthly & 0.29 & 0.455 & 0 & 1 & $\begin{array}{l}\text { Own calculations based } \\
\text { on definitions by } \\
\text { Woldendorp et al. (2000) }\end{array}$ \\
\hline $\begin{array}{l}\text { Government ideo- } \\
\text { logy (Taxes vs. } \\
\text { Spending) }\end{array}$ & $\begin{array}{l}\text { Index (0: high } \\
\text { spending; 20: } \\
\text { low taxes) }\end{array}$ & monthly & 11.15 & 3.256 & 5.31 & 16.70 & $\begin{array}{l}\text { Own calculations based } \\
\text { on Benoit and Laver } \\
(2006)\end{array}$ \\
\hline Trust & $\begin{array}{l}\text { Share of respondents } \\
\text { who trust }\end{array}$ & monthly & 0.38 & 0.170 & 0.10 & 0.76 & $\begin{array}{l}\text { Integrated EVS/WVS } \\
\text { 1981-2008 Data File, } \\
\text { interpolated between } \\
\text { waves }\end{array}$ \\
\hline Inflation history & in $\%$ of GDP & constant & 8.45 & 4.452 & 2.83 & 19.56 & OECD \\
\hline
\end{tabular}


Table 4: FEVD estimations of yield spreads on FRI sub-indicators

\begin{tabular}{lccccc}
\hline \hline & $(1)$ & $(2)$ & $(3)$ & $(4)$ & $(5)$ \\
\hline Index balanced & $-0.022^{* *}$ & & & & -0.015 \\
budget rules & $(-2.249)$ & & & & $(-1.231)$ \\
Index debt rules & & -0.025 & & & -0.018 \\
& & $(-1.519)$ & & & $(-0.945)$ \\
Index expenditure & & & -0.012 & & -0.024 \\
rules & & & $(-0.782)$ & & $(-1.377)$ \\
Index revenue rules & & & & -0.007 & 0.006 \\
& & & & $(-0.535)$ & $(0.355)$ \\
Debt & 0.001 & 0.001 & 0.001 & 0.002 & 0.000 \\
& $(1.025)$ & $(0.922)$ & $(0.859)$ & $(1.163)$ & $(0.289)$ \\
Deficit & 0.008 & $0.010^{*}$ & $0.014^{* *}$ & 0.009 & $0.014^{* *}$ \\
& $(1.233)$ & $(1.726)$ & $(2.094)$ & $(1.464)$ & $(2.077)$ \\
Liquidity & -0.020 & 0.140 & -0.161 & -0.128 & 0.073 \\
& $(-0.045)$ & $(0.279)$ & $(-0.307)$ & $(-0.252)$ & $(0.150)$ \\
Risk aversion & $0.070^{* * *}$ & $0.070^{* * *}$ & $0.071^{* * *}$ & $0.070^{* * *}$ & $0.071^{* * *}$ \\
& $(5.025)$ & $(5.061)$ & $(5.030)$ & $(4.956)$ & $(5.160)$ \\
EMU & 0.089 & 0.082 & $0.146^{* *}$ & $0.137^{* *}$ & 0.089 \\
& $(1.539)$ & $(1.225)$ & $(2.034)$ & $(1.978)$ & $(1.506)$ \\
\hline No. of observations & 2,403 & 2,403 & 2,403 & 2,403 & 2,403 \\
No. of countries & 15 & 15 & 15 & 15 & 15 \\
$R^{2}$ & 0.578 & 0.592 & 0.590 & 0.579 & 0.602 \\
\hline \hline
\end{tabular}

